\title{
The Differences Among Disciplines in Scholarly Communication: A Bibliometric Analysis of Theses
}

\author{
Nazan Özenç Uçak and Umut Al \\ Department of Information Management, Hacettepe University, Ankara, Turkey
}

\begin{abstract}
The purpose of this paper is to express the differences and similarities of inter-disciplinary scholarly communications through the citation analysis of theses. For this purpose, a total of 29,289 citations from 391 theses between years 1968-2007 were investigated using citation analysis. Samples were chosen according to layer-sampling techniques from 16 disciplines of four basic subject areas (social sciences, pure science, engineering, and arts and humanities). It has been found out that the characteristics of citations of the theses differ among academic disciplines. The study finds that literature obsolescence, language of resources, journal or monograph use, number of citations and authors are related to the disciplines and vary according to the subject areas.
\end{abstract}

\section{Introduction}

Scientific communication, as a form of communication, involves scientists' activities done with the help of formal and informal studies. Different fields of science vary in their research techniques and ways of using publications. The characteristics of the information needed affect the sources of information. While articles with up-to-date information are needed in some disciplines, books constitute the fundamental sources of information in others. It is possible to see various types of information about the scientific communication process of a field of science in theses. Therefore, by analyzing theses and reference lists, it is possible to obtain information about which techniques have been used to conduct research, which materials are commonly used in the fields in question, and whether recent or older information is needed. These kinds of findings about scientific communication are obtained through bibliometric research. The information obtained from these types of research especially helps information centres to establish their collection policies. 
The purpose of this study is to identify the differences in scientific communication among disciplines by analyzing the citations in theses. It aims to address the following research questions:

- Do the sources cited in theses vary according to fields of science?

- What is the rate of literature obsolescence in various disciplines?

- Are Master and $\mathrm{PhD}$ theses different from each other in terms of their citation practices?

To answer the research questions, 391 Master and $\mathrm{PhD}$ theses are examined, first, in terms of their bibliometric features such as year, number of pages, number of citations and second, in terms of the sources cited such as type of publication, language, number of authors in the citations.

\section{The Literature on Bibliometric Studies of Theses}

Many studies have been conducted on theses in different disciplines in the literature (Buttlar 1999; Edwards 1999; Gooden 2001; Herubel 1991; Kushkowski, Parsons \& Wiese 2003; Kuyper-Rushing 1999; Sylvia \& Lesher 1995; Walcott 1991, 1994; Waugh \& Ruppel 2004; Wehmeyer \& Wehmeyer 1999; Zipp 1996). In these studies, along with various bibliometric analyses, content analyses of theses were conducted and the research and collecting information techniques were examined.

In terms of quantity, citation analysis studies on library and information science theses are worthy of attention (Buttlar 1999; Clarke \& Oppenheim 2006; Tonta \& Al 2006). The most common research topics in these studies are the kinds of journals and publications used and the age of the sources referred. In one of these studies, it was found that the number of citations to journal articles is more than the sum of citations to other kinds of publications (Buttlar 1999).

In some other studies, by analyzing the citations in theses, collection management and development decisions for special collections are made (Edwards 1999; Sylvia \& Lesher 1995; Zipp 1996). These kinds of findings could benefit the decisions on library journal subscriptions (Sylvia \& Lesher 1995). A similar suggestion was put forward during a study of the citations in the chemistry theses, which suggested that less-cited journals could have been sorted out by considering their cost (Edwards 1999, 19). 
In another study (Kuyper-Rushing 1999, 160), the citations in theses related to music were examined in order to identify the core journal collection in music libraries, and it was revealed that in the field of music, books (41\%) are used more than periodicals (29\%). On the other hand, in a citation analysis study conducted on philosophy theses, it was revealed that citations to books are three times more numerous than citations to journals (Herubel 1991, 67). In science theses, there are more citations to articles published in scientific journals than citations to other types of publications. In chemistry $\mathrm{PhD}$ theses, $86 \%$ of the citations are to articles in journals (Gooden 2001). This rate is $80 \%$ in earth sciences and $90 \%$ in biology (Walcott 1991, 9; 1994, 4).

The engineering and social sciences theses written in Iowa State University between 1973 and 1992 were compared to the fine arts and humanities theses; results were that the engineering and social sciences theses have citations to more recent sources (Kushkowski, Parsons \& Wiese 2003, 467).

Many research studies have been conducted on theses in other fields and disciplines. The research conducted in 1991 on the citations of 51 theses in the field of philosophy (Herubel 1991) was followed by other citation analysis studies on the fields of education (Okiy 2003; Beile, Boote \& Killingsworth 2004; Haycock 2004), library science (Gökkurt 1997a; Buttlar 1999; Clarke \& Oppenheim 2006; Tonta \& Al 2006), English language (Slutz 1997), law (Sexton 2006), music (Kuyper-Rushing 1999), clinical psychology (Wehmeyer \& Wehmeyer 1999), chemistry (Edwards 1999; Gooden 2001), forestry (Brazzeal \& Fowler 2005), and mathematics and statistics (Sinn 2005).

In Turkey, the research on theses can be divided into two categories: content analysis and citation analysis studies. In content analysis studies, data collection techniques and research topics were analyzed (Yllmaz 1997; Yontar 1998; Uçak 2004, 2007). On the other hand, citation analysis studies started later and are fewer in number (Gökkurt 1997b; Yılmaz 1999; $\mathrm{Al}$ and Tonta 2004).

\section{Research Method}

In this study, the bibliometric features of the theses collected in Hacettepe University between 1968 and 2007 were examined in order to reveal the differences among different disciplines in scientific communication. It was observed that social sciences, pure sciences, engineering, arts and humanities are the fields represented for choosing the disciplines to be 
studied. Four different disciplines were chosen in each field. These disciplines were Economics, Psychology, Sociology and Aistory for social sciences; Biology, Statistics, Chemistry, and Mathematics for pure sciences; Computer Engineering, Electrical and Electronic Engineering, Physics Engineering and Chemical Engineering for engineering; Philosophy, English Language and Literature, Art and Ceramics for arts and humanities.

The data of the study were collected and evaluated with the help of citation analysis. Citation analysis is widely applied to the bibliographic data from articles and monographs. Using citation analysis on graduate theses makes it possible to understand scholarly communications in the past ten years.

A sample of 391 theses was determined by weighing an $11.1 \%$ sampling rate and layers. The distribution in the layered sampling process for the theses was achieved taking both the disciplines and the type of the theses (Master or $\mathrm{PhD}$ ) into consideration. Table 1 illustrates how many theses were taken from which categories in the sample.

Table 1. Sampling statistics

\begin{tabular}{lrrc}
\hline Department & Population & Sample & Sample rate (\%) \\
\hline Psychology & 170 & 19 & 11.2 \\
Sociology & 244 & 28 & 11.5 \\
History & 403 & 45 & 11.2 \\
Economics & 23 & 3 & 13.0 \\
Statistics & 244 & 27 & 11.1 \\
Chemistry & 359 & 40 & 11.1 \\
Mathematics & 261 & 29 & 11.1 \\
Biology & 407 & 45 & 11.1 \\
Physics Engineering & 235 & 26 & 11.1 \\
Chemical Engineering & 244 & 27 & 11.1 \\
Electrical \& Electronic Engineering & 270 & 29 & 10.7 \\
Computer Engineering & 114 & 13 & 11.4 \\
Philosophy & 90 & 10 & 11.1 \\
English Language and Literature & 210 & 23 & 11.0 \\
Art & 177 & 20 & 11.3 \\
Ceramics & 69 & 7 & 10.1 \\
Total & $\mathbf{3 , 5 2 0}$ & $\mathbf{3 9 1}$ & $\mathbf{1 1 . 1}$ \\
\hline
\end{tabular}

Chi-Square, Pearson Correlation and Kruskal-Wallis tests were used in the study. In the analysis of the data obtained from the citation analysis, Microsoft Excel and Statistical Package for the Social Sciences (SPSS) programs were used.

\section{Findings and Discussion}

In the scope of this research study, the 391 theses, chosen by means of sampling, have been examined. There were 276 (71\%) Masters theses and 115 (29\%) PhD theses. While the 
average number of pages in Masters' theses is 92, that number almost doubles (170) in $\mathrm{PhD}$ theses.

\section{The Distribution of Number of Pages and Citations}

The total number of sources cited in the theses is 29,289 and the average number of sources cited in the theses is 75 ( $\mathrm{SD}=77$, $\min .=3$, max. $=686$ ). The average number of citations in $\mathrm{PhD}$ theses (121) is more than two times the average number of citations in Master theses (56). The study found that the higher the number of pages, the higher the number of citations (Pearson's $r=.681 . p<.01$ ).

Examined in terms of number of pages, social sciences theses ( $\bar{X}=140$ pages) are two times longer than pure sciences theses ( $\bar{X}=70$ pages). The Master theses in engineering are 86 pages on average, whereas arts and humanities theses are 77 pages on average.

In terms of number of pages, the same phenomena in the Master theses in fields of study can be observed in the $\mathrm{PhD}$ theses as well. The social sciences $\mathrm{PhD}$ theses are found to be the longest ones. They are followed by engineering, arts and humanities and pure sciences respectively. When the disciplines are examined specifically, the $\mathrm{PhD}$ theses with the fewest pages are in the disciplines of Mathematics, Arts and Chemical Engineering. 
Table 2. Number of pages and citations of theses

\begin{tabular}{|c|c|c|c|c|c|c|c|c|c|c|c|c|c|c|}
\hline \multirow[b]{3}{*}{ Disciplines and fields } & \multicolumn{2}{|c|}{ \# of theses } & \multicolumn{6}{|c|}{ \# of pages } & \multicolumn{6}{|c|}{ \# of citations } \\
\hline & \multirow[b]{2}{*}{ Master } & \multirow[b]{2}{*}{ PhD } & \multicolumn{2}{|c|}{ Master } & \multirow[b]{2}{*}{ SS } & \multicolumn{3}{|c|}{$\underline{\text { PhD }}$} & \multicolumn{3}{|c|}{ Master } & \multicolumn{3}{|c|}{$\underline{\text { PhD }}$} \\
\hline & & & $\mathbf{N}$ & $\bar{X}$ & & $\mathbf{N}$ & $\bar{X}$ & SS & $\mathbf{N}$ & $\bar{X}$ & SS & $\mathbf{N}$ & $\bar{X}$ & SS \\
\hline Psychology & 15 & 4 & 1599 & 107 & 43 & 777 & 194 & 47 & 1200 & 80 & 46 & 546 & 137 & 50 \\
\hline Sociology & 18 & 10 & 3093 & 172 & 63 & 2825 & 283 & 77 & 1788 & 99 & 82 & 1923 & 192 & 105 \\
\hline History & 30 & 15 & 4188 & 140 & 58 & 4978 & 332 & 138 & 3764 & 125 & 54 & 4326 & 288 & 139 \\
\hline Economics & 2 & 1 & 207 & 104 & 23 & 171 & 171 & - & 83 & 42 & 5 & 112 & 112 & - \\
\hline Social sciences & 65 & 30 & 9087 & 140 & 60 & 8751 & 292 & 118 & 6835 & 105 & 64 & 6907 & 230 & 130 \\
\hline Statistics & 20 & 7 & 1626 & 81 & 31 & 778 & 111 & 13 & 550 & 28 & 12 & 274 & 39 & 15 \\
\hline Chemistry & 24 & 16 & 1651 & 69 & 14 & 1872 & 117 & 37 & 1638 & 68 & 44 & 1381 & 86 & 57 \\
\hline Mathematics & 21 & 8 & 1256 & 60 & 11 & 531 & 66 & 18 & 343 & 16 & 9 & 212 & 27 & 20 \\
\hline Biology & 29 & 16 & 2059 & 71 & 39 & 1878 & 117 & 35 & 1937 & 67 & 32 & 1823 & 114 & 58 \\
\hline Pure sciences & 94 & 47 & 6592 & 70 & 28 & 5059 & 108 & 36 & 4468 & 48 & 37 & 3690 & 79 & 58 \\
\hline Physics Engineering & 17 & 9 & 1295 & 76 & 32 & 1468 & 163 & 92 & 567 & 33 & 26 & 625 & 69 & 43 \\
\hline Chemical Engineering & 21 & 6 & 1713 & 82 & 37 & 581 & 97 & 36 & 1032 & 49 & 27 & 655 & 109 & 95 \\
\hline Electrical \& Electronic & & & 2659 & 98 & 44 & 333 & 167 & 6 & 689 & 26 & 15 & 162 & 81 & 20 \\
\hline Engineering & 27 & 2 & & & & & & & & & & & & \\
\hline Computer Engineering & 11 & 2 & 858 & 78 & 20 & 615 & 308 & 139 & 248 & 23 & 12 & 373 & 187 & 86 \\
\hline Engineering & 76 & 19 & 6525 & 86 & 37 & 2997 & 158 & 95 & 2536 & 33 & 23 & 1815 & 96 & 71 \\
\hline Philosophy & 7 & 3 & 690 & 99 & 34 & 620 & 207 & 93 & 372 & 53 & 26 & 382 & 127 & 90 \\
\hline English Language and & & & 1518 & 101 & 64 & 1273 & 159 & 58 & 709 & 47 & 29 & 765 & 96 & 56 \\
\hline Literature & 15 & 8 & & & & & & & & & & & & \\
\hline Art & 14 & 6 & 696 & 50 & 20 & 549 & 92 & 28 & 250 & 18 & 9 & 162 & 27 & 8 \\
\hline Ceramics & 5 & 2 & 253 & 51 & 21 & 298 & 149 & 146 & 198 & 40 & 14 & 200 & 100 & 105 \\
\hline Arts and humanities & 41 & 19 & 3157 & 77 & 49 & 2740 & 144 & 73 & 1529 & 37 & 26 & 1509 & 79 & 65 \\
\hline Total & 276 & 115 & 25,361 & 92 & 51 & 19,547 & 170 & 109 & 15,368 & 56 & 49 & 13,921 & 121 & 107 \\
\hline
\end{tabular}


The reference lists of the theses in the field of social sciences had more citations compared to the theses in the other fields. This situation is valid for both Master and $\mathrm{PhD}$ theses. As can be seen in Table 2, the average number of citations is 56 in Master theses and 121 in $\mathrm{PhD}$ theses. These averages are higher than the average numbers of citations of the fields other than social sciences. Although a limited number of citations are used in the Master theses in the field of engineering, the average number of citations in the $\mathrm{PhD}$ theses is three times more than the Master theses in the same field.

The results turn out to be significant when evaluated with the Kruskal-Wallis test $(H=$ $107,88$ d.f. $=3 . p<.01)$. In terms of the order of the averages, the highest average belongs to social sciences.

In terms of disciplines, mathematics and art are the disciplines which use the fewest number of citations, as well as having the fewest pages. The $\mathrm{PhD}$ theses in these two disciplines include an average of 27 sources. Eighteen (18) sources are cited in the Master theses in art, whereas in mathematics, 16 sources are cited.

Among the social sciences theses, the highest number of sources is used in history, whereas the fewest number is used in Economics. History was the discipline with the highest number of citations not only in social sciences, but also in all the 16 disciplines both in Master and $\mathrm{PhD}$ theses.

In the pure sciences, except Biology, the number of sources cited in the Master and $\mathrm{PhD}$ theses is close to each other. In the theses related to Mathematics and Statistics among pure sciences, it is observed that the number of citations is fewer than the theses in other fields.

The $\mathrm{PhD}$ theses in engineering are completed with many more citations compared to the Master theses. Among the Master theses in engineering, the discipline with the lowest number of citations is Electrical and Electronic Engineering.

The average number of citations in Philosophy within arts and humanities is more than the citations in the other disciplines. In terms of the average number of citations in $\mathrm{PhD}$ theses, Philosophy is followed by Ceramics, English Language and Literature and Art respectively. 


\section{The Sources Cited and Their Distribution}

The distribution of the sources cited in theses constitutes a fundamental part of our study. According to our findings, $48 \%$ of the citations in the reference lists of the theses are made to books, $42 \%$ to journals, $3 \%$ to proceedings and $2 \%$ to theses. The rest of the citations are made to Web sources, unpublished studies, interviews or archives. The types of sources cited differ according to fields. The Chi-square analysis indicates that there is a statistically significant difference among the cited sources according to fields and types of publications $(\chi 2=8013,857$ d.f. $=15, p<.01)$.

In addition to the differences among fields, there are also differences among disciplines in the same field in terms of the types of sources cited. Thus, it is useful to consider the fields separately and examine the use of sources across the disciplines that these fields include.

\section{$\underline{\text { Social Sciences }}$}

In general, citations in social sciences theses mostly consist of books. The citations made to books are nearly two and a half times more than the citations made to journals. While the rate of citations to journals is $19 \%$ in Economics, $19.2 \%$ in Sociology and $19.6 \%$ in History, this rate jumps as high as $66.6 \%$ in Psychology. There are many studies that draw attention to the common use of journals in the field of Psychology (Schaffer 2004; Shontz 1992; Wehmeyer \& Wehmeyer 1999; Xhignesse \& Osgood 1967). Sociology is the discipline where books constitute the most cited sources. The rate of citations to theses in Psychology is 3.3\% and the rate of citations to proceedings in Sociology is 4.8\%. Also, unpublished reports in Economics and archives in History are cited very often.

It can be seen in the citation analysis research in the literature that in social sciences citations to monographs are common (Broadus 1971; Clemens et al. 1995; Lindholm-Romantschuk \& Warner 1996). In one of these studies, it was shown that in Sociology, citations to books are 2.6 times greater than citations to articles (Lindholm-Romantschuk \& Warner 1996, 395). The data obtained in this research study is parallel to the findings reported in the literature.

\section{Pure Sciences}

In pure sciences theses, the majority of the citations are made to journals. In the field of Chemistry, citations to journals constituted $80 \%$ of all the citations. In Biology, this rate is 75\%; whereas it is 53\% in Mathematics and 51\% in Statistics. In Mathematics and Statistics theses, the rate of citations to books is $36 \%$ (see Table 3). In Statistics theses, software 
programs are cited to an extent. Such citations, which are not used very frequently, are classified as "other". In the pure sciences, the discipline of Statistics stands out with its citations under the category of "other". In the pure sciences, citations made to theses ranked third, with a rate of $2.1 \%$.

\section{Engineering}

Similarly to pure sciences, the field of engineering is a field in which scientific communication is established mostly through journals. When examined according to disciplines, the use of journals is fairly common especially in Physics (73.1\%) and Chemical Engineering (68.7\%) (see Table 3). In Electrical and Electronic Engineering, it is seen that the citations to books are greater than the citations to journals, and citations to proceedings rank third, with a rate of $10 \%$. In addition, Computer Engineering has the highest rate of citations to proceedings by $16 \%$, among the disciplines in this study. Among all fields, the highest rate of citations to proceedings belongs to engineering. In the field of engineering, proceedings consists of $6.2 \%$ of the cited sources, whereas in social sciences this rate drops to $3.4 \%$, in pure sciences to $2 \%$ and finally in arts and humanities to $0.4 \%$.

In the Electrical and Electronic Engineering and Computer Engineering theses, it has been found out that Web sources were used by over 5\%. In literature, the common use of journals by engineers is highlighted by Pinelli (1991) and Pinelli et al. (1993). In addition, Tenopir and King (2004) stress the recent use of electronic sources in the field of engineering. The results obtained in this research indicate that the use of electronic sources in the field of engineering is less than the findings in the literature. It is also seen that the majority of the citations categorized as others in engineering theses are made to unpublished lecture notes and softwares. 
Table 3. Distribution of citations by publication types

\begin{tabular}{|c|c|c|c|c|c|c|c|c|c|c|c|c|c|c|}
\hline \multirow[b]{2}{*}{ Disciplines and fields } & \multicolumn{2}{|c|}{ Books } & \multicolumn{2}{|c|}{ Journals } & \multicolumn{2}{|c|}{ Theses } & \multicolumn{2}{|c|}{ E-sources } & \multicolumn{2}{|c|}{ Proceedings } & \multicolumn{2}{|c|}{ Other } & \multicolumn{2}{|c|}{ Total } \\
\hline & $\mathbf{N}$ & $\%$ & $\mathbf{N}$ & $\%$ & $\mathbf{N}$ & $\%$ & $\mathbf{N}$ & $\%$ & $\mathbf{N}$ & $\%$ & $\overline{\mathbf{N}}$ & $\%$ & $\mathbf{N}$ & $\%$ \\
\hline Psychology & 457 & 26.2 & 1162 & 66.6 & 58 & 3.3 & - & - & 53 & 3.0 & 16 & 0.9 & 1746 & 100.0 \\
\hline Sociology & 2624 & 70.7 & 713 & 19.2 & 49 & 1.3 & 55 & 1.5 & 179 & 4.8 & 91 & 2.5 & 3711 & 100.0 \\
\hline History & 5433 & 67.2 & 1583 & 19.6 & 81 & 1.0 & 42 & 0.5 & 230 & 2.8 & 721 & 8.9 & 8090 & 100.0 \\
\hline Economics & 107 & 54.9 & 37 & 19.0 & 1 & 0.5 & - & - & 8 & 4.1 & 42 & 21.5 & 195 & 100.0 \\
\hline Social sciences & 8621 & 62.7 & 3495 & 25.4 & 189 & 1.4 & 97 & 0.7 & 470 & 3.4 & 870 & 6.3 & 13,742 & 99.9 \\
\hline Statistics & 294 & 35.7 & 420 & 51.0 & 29 & 3.5 & 14 & 1.7 & 24 & 2.9 & 43 & 5.2 & 824 & 100.0 \\
\hline Chemistry & 446 & 14.8 & 2421 & 80.2 & 33 & 1.1 & 2 & 0.1 & 34 & 1.1 & 83 & 2.7 & 3019 & 100.0 \\
\hline Mathematics & 200 & 36.0 & 295 & 53.2 & 15 & 2.7 & 25 & 4.5 & 14 & 2.5 & 6 & 1.1 & 555 & 100.0 \\
\hline Biology & 707 & 18.8 & 2804 & 74.6 & 93 & 2.5 & 26 & 0.7 & 93 & 2.5 & 37 & 1.0 & 3760 & 100.0 \\
\hline Pure sciences & 1647 & 20.2 & 5940 & 72.8 & 170 & 2.1 & 67 & 0.8 & 165 & 2.0 & 169 & 2.1 & 8158 & 100.0 \\
\hline Physics Engineering & 221 & 18.5 & 871 & 73.1 & 26 & 2.2 & - & - & 40 & 3.4 & 34 & 2.9 & 1192 & 100.1 \\
\hline $\begin{array}{l}\text { Chemical Engineering } \\
\text { Electrical \& Electronic }\end{array}$ & 368 & 21.8 & 1159 & 68.7 & 47 & 2.8 & 16 & 0.9 & 45 & 2.7 & 52 & 3.1 & 1687 & 100.0 \\
\hline Engineering & 359 & 42.2 & 295 & 34.7 & 27 & 3.2 & 48 & 5.6 & 86 & 10.1 & 36 & 4.2 & 851 & 100.0 \\
\hline Computer Engineering & 169 & 27.2 & 300 & 48.3 & 9 & 1.4 & 33 & 5.3 & 100 & 16.1 & 10 & 1.6 & 621 & 99.9 \\
\hline Engineering & 1117 & 25.7 & 2625 & 60.3 & 109 & 2.5 & 97 & 2.2 & 271 & 6.2 & 132 & 3.0 & 4351 & 99.9 \\
\hline Philosophy & 701 & 93.0 & 47 & 6.2 & 6 & 0.8 & - & - & - & - & - & - & 754 & 100.0 \\
\hline English Language and & & & & & & & & & & & & & & \\
\hline Literature & 1285 & 87.2 & 151 & 10.2 & 5 & 0.3 & 32 & 2.2 & 1 & 0.1 & - & - & 1474 & 100.0 \\
\hline Art & 361 & 87.6 & 36 & 8.7 & 1 & 0.2 & 12 & 2.9 & 1 & 0.2 & 1 & 0.2 & 412 & 99.8 \\
\hline Ceramics & 314 & 78.9 & 42 & 10.6 & 7 & 1.8 & 17 & 4.3 & 11 & 2.8 & 7 & 1.8 & 398 & 100.2 \\
\hline Arts and humanities & 2661 & 87.6 & 276 & 9.1 & 19 & 0.6 & 61 & 2.0 & 13 & 0.4 & 8 & 0.3 & 3038 & 100.0 \\
\hline Total & 14,046 & 48.0 & 12,336 & 42.1 & 487 & 1.7 & 322 & 1.1 & 919 & 3.1 & 1179 & 4.0 & 29,289 & 100.0 \\
\hline
\end{tabular}




\section{$\underline{\text { Arts and Humanities }}$}

In arts and humanities, the majority of cited sources are books. Generally speaking, journals are less than $10 \%$ of the citations. Philosophy is the discipline in which books are used the most, with a rate of 93\%. Philosophy is followed by arts at $87.6 \%$, English Language and Literature at $87.2 \%$, and Ceramics at $78.9 \%$. The disciplines in arts and humanities, other than Philosophy, use the Internet as well, although to a limited extent. In the theses in Ceramics, electronic sources are cited approximately 5\% of the time. Among the sources cited in arts and humanities, proceedings constitute a very low number (see Table 3).

Citation analysis studies conducted at various times on sub-disciplines of arts and humanities also point out the frequent use of books (Cullars 1992; Heinzkill 1980; Stern 1983). In research in the field of Literature, arts and humanities were found to have a tendency towards using books, and $80 \%$ of the citations in the reference lists of the sources in the field of Literature consist of books (Stern 1983, 207). The results obtained in this study verify the importance of books in this field.

\section{Literature Obsolescence}

In this study, along with the half-life of the citations in theses, the $60 \%, 70 \%, 80 \%$ and $90 \%$ obsolescence rates are calculated (see Table 4). Out of 29,289 citations examined, 788 have been excluded from the evaluation process as the publication dates were not stated. A total of 28,501 citations with publication dates have been put in order according to the publication dates of the cited source which covers a period between 1006 and 2007. In order to find the half-life of the sources cited in theses, the publication dates of all the sources cited are subtracted from the publication date of the theses in which they are cited and the median of the cited sources was calculated. This process has been applied to fields and disciplines separately. The results show that the half-life of the sources cited in the 16 disciplines that are in the scope of the study is 12 years.

In terms of fields, it is seen that the fastest obsolescence is in the field of engineering. The half-life of the citations in the engineering theses is 8 years. In addition, it is observed that the half-life of the sources in the field of arts and humanities theses is 10 years while it is 11 years in pure sciences theses and 14 years in social sciences theses. 
Table 4. Obsolescence rates for disciplines and fields

\begin{tabular}{lrrrrr}
\hline Disciplines and fields & $\mathbf{5 0 \%}$ & $\mathbf{6 0 \%}$ & $\mathbf{7 0 \%}$ & $\mathbf{8 0 \%}$ & $\mathbf{9 0 \%}$ \\
\hline Psychology & 9 & 11 & 13 & 17 & 23 \\
Sociology & 10 & 13 & 18 & 24 & 35 \\
History & 21 & 28 & 39 & 59 & 84 \\
Economics & 7 & 8 & 10 & 13 & 15 \\
$\quad$ Social sciences & $\mathbf{1 4}$ & $\mathbf{1 9}$ & $\mathbf{2 6}$ & $\mathbf{3 9}$ & $\mathbf{6 7}$ \\
Statistics & 11 & 13 & 17 & 21 & 29 \\
Chemistry & 13 & 16 & 19 & 24 & 34 \\
Mathematics & 14 & 18 & 21 & 26 & 35 \\
Biology & 10 & 12 & 15 & 19 & 25 \\
$\quad$ Pure sciences & $\mathbf{1 1}$ & $\mathbf{1 4}$ & $\mathbf{1 7}$ & $\mathbf{2 2}$ & $\mathbf{2 9}$ \\
Physics Engineering & 10 & 12 & 17 & 22 & 29 \\
Chemical Engineering & 10 & 12 & 14 & 18 & 25 \\
Electrical \& Electronic Engineering & 8 & 11 & 13 & 17 & 23 \\
Computer Engineering & 5 & 6 & 7 & 9 & 12 \\
$\quad$ Engineering & $\mathbf{8}$ & $\mathbf{1 1}$ & $\mathbf{1 3}$ & $\mathbf{1 8}$ & $\mathbf{2 5}$ \\
Philosophy & 10 & 13 & 17 & 23 & 32 \\
English Language and Literature & 12 & 15 & 19 & 24 & 33 \\
Art & 8 & 10 & 12 & 15 & 21 \\
Ceramics & 8 & 10 & 12 & 15 & 21 \\
$\quad$ Arts and humanities & $\mathbf{1 0}$ & $\mathbf{1 3}$ & $\mathbf{1 6}$ & $\mathbf{2 1}$ & $\mathbf{3 0}$ \\
For all theses & $\mathbf{1 2}$ & $\mathbf{1 5}$ & $\mathbf{2 0}$ & $\mathbf{2 6}$ & $\mathbf{4 2}$ \\
\hline
\end{tabular}

In terms of disciplines, our study shows that History has the slowest rate of obsolescence. Half of the citations in History theses are 21 years and older. In social sciences, obsolescence in Economics and Psychology is faster than in Sociology and History. While the half-life in Economics is 7 years, it is 9 years in Psychology. In Economics, 90\% of the citations are to sources written within the last 15 years, as compared to 23 years for Psychology, 35 years for Sociology, and 84 years for History. These results indicate that old sources are also essential when organizing collections for social science theses and especially for the discipline of History (see Figure 1).

The disciplines in pure sciences are similar to each other in terms of literature obsolescence. The fastest literature obsolescence is observed in the discipline of Biology, whereas Mathematics proved to have the slowest literature obsolescence. The discipline of Mathematics is followed by Chemistry in terms of slow obsolescence rate. The half-life of the sources in citations is 14 years in Mathematics theses and 13 years in Chemistry theses. 


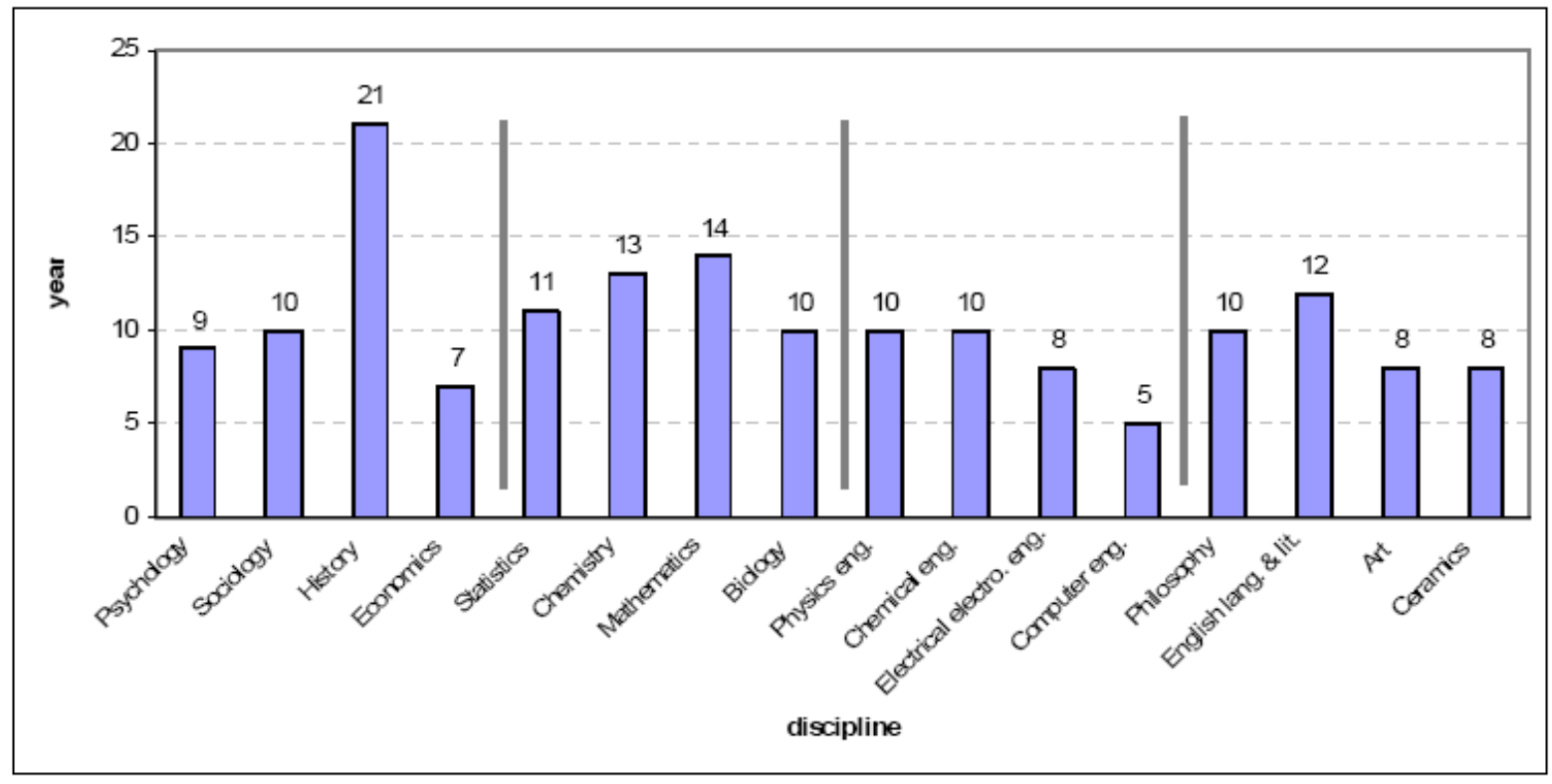

Figure 1. The half-life of the citations according to disciplines

Among the four different fields, engineering is the one with the fastest obsolescence rate. In this field, Computer Engineering stands out as the one in which recent sources are the most frequently used. Half of the citations in Computer Engineering are to sources published in the last five years. In addition, it is seen that Electrical and Electronic Engineering has the tendency of using recent sources more frequently, compared to Physics and Chemical Engineering. In the citation analysis study of Cunningham and Bocock $(1995,258)$ on computer sciences, the half-life is close to one found in this study. Finally certain journals in the computer sciences are examined and the median age of citation is found out to be 4 years.

The half-life of the sources cited in arts and humanities theses is 10 years. In terms of literature obsolescence, English Language and Literature and Philosophy are different from the disciplines of arts. The half-life in English Language and Literature is 12 years and in Philosophy 10 years, while in arts thesis, the literature obsolescence occurs faster and the half-life is 8 years (see Figure 1).

\section{Obsolescence Rates According to Type of Publication}

Our study categorizes the sources cited in terms of their types and their literature obsolescence rates are analyzed in terms of the type of publication cited. As a result, their half-life as well as literature obsolescence rates by 60\%, 70\%, 80\% and 90\% are calculated separately. The results show that the half-life is 13 years for books, 11 years for journals, 6 years for theses, 1 year for Internet sources and 8 years for proceedings. The citations to 
journals usually become obsolete more quickly than the citations to books. To evaluate, it can be argued that the slowest obsolescence rate is in books, while the fastest is in electronic sources. It is also worth mentioning that theses are used more frequently in a time period that is close to their submission date (see Table 5).

Table 5. Number of citations and obsolescence rates according to type of publication

\begin{tabular}{lrrrrrr}
\hline Type of publication & \# of citations & $\mathbf{5 0 \%}$ & $\mathbf{6 0} \%$ & $\mathbf{7 0 \%}$ & $\mathbf{8 0 \%}$ & $\mathbf{9 0 \%}$ \\
\hline Books & 13,742 & 13 & 16 & 21 & 28 & 42 \\
Journals & 12,287 & 11 & 14 & 18 & 24 & 39 \\
Theses & 483 & 6 & 8 & 11 & 13 & 19 \\
E-sources & 217 & 1 & 2 & 3 & 3 & 5 \\
Proceedings & 912 & 8 & 10 & 11 & 15 & 25 \\
Other & 860 & 27 & 60 & 69 & 76 & 132 \\
For all types & $\mathbf{2 8 , 5 0 1}$ & $\mathbf{1 2}$ & $\mathbf{1 5}$ & $\mathbf{2 0}$ & $\mathbf{2 6}$ & $\mathbf{4 2}$ \\
\hline
\end{tabular}

The half-life of the citations to books and journals in social sciences are identified as 14 years each. However, some differences among disciplines are striking. For instance, the half-life of the citations to journals in History theses is 39 years. On the other hand, the number drops to 17 in the same discipline when it comes to books. While Sociology and Psychology bear similarities in terms of obsolescence, Economics has the fastest literature obsolescence among the disciplines of social sciences.

In pure sciences, the fastest obsolescence in books is in Statistics while the fastest obsolescence in journals is in Biology. The half life of the citations to journals in Biology is 10 years, as compared to 11 years in Statistics, 13 years in Chemistry and 15 years in Mathematics. In books, this rate is 12 years in Biology and 16 years in Chemistry and Mathematics (see Table 6).

In engineering, books become obsolete more slowly in Physics and Chemical Engineering than they do in Electrical and Electronic and Computer Engineering. While the half life of the books in Physics and Chemical Engineering is 13 years, it is 8 years in Electrical and Electronic Engineering and 6 years in Computer Engineering. In Physics, Chemical and Computer Engineering, the citations to journals are younger than the citations to books. As opposed to the general trend, it has been found out that in Electrical and Electronic Engineering theses the citations to journals become obsolete more slowly than the citations to books. The half-life of the citations to books in Electrical and Electronic Engineering theses 
is 8 years; whereas the half-life of the citations to journals was 11 years. Regarding the obsolescence rates of proceedings, which constitute an important source of information in engineering, it has been discovered that the fastest obsolescence occurs in Chemical and Computer Engineering by 5 years. The slowest obsolescence rate is in Physics (see Table 6).

Table 6. Half-life for fields and types of publication

\begin{tabular}{|c|c|c|c|c|c|c|c|}
\hline Disciplines and fields & Books & Journals & Theses & E-sources & Proceedings & Other & All \\
\hline Psychology & 11 & 9 & 6 & - & 6 & 4 & 9 \\
\hline Sociology & 11 & 10 & 8 & 1 & 6 & 4 & 10 \\
\hline History & 17 & 39 & 9 & 2 & 16 & 125 & 21 \\
\hline Economics & 8 & 6 & 5 & - & 9 & 4 & 7 \\
\hline Social sciences & 14 & 14 & 8 & 1 & 9 & 65 & 14 \\
\hline Statistics & 11 & 11 & 7 & 2 & 10.5 & 5 & 11 \\
\hline Chemistry & 16 & 13 & 15 & 10 & 11 & 14 & 13 \\
\hline Mathematics & 16 & 15 & 7.5 & 3 & 10 & 7 & 14 \\
\hline Biology & 12 & 10 & 8 & 4 & 5 & 5 & 10 \\
\hline Pure sciences & 13 & 11 & 7 & 1 & 7 & 9 & 11 \\
\hline Physics Engineering & 13 & 10 & 6 & - & 11 & 5 & 10 \\
\hline $\begin{array}{l}\text { Chemical Engineering } \\
\text { Electrical \& Electronic }\end{array}$ & 13 & 9 & 4 & 3 & 5 & 11 & 10 \\
\hline Engineering & 8 & 11 & 4 & 1 & 9 & 6 & 8 \\
\hline Computer Engineering & 6 & 5 & 6 & 0 & 5 & 3 & 5 \\
\hline Engineering & 10 & 9 & 4 & 1 & 7 & 7 & 8 \\
\hline $\begin{array}{l}\text { Philosophy } \\
\text { English Language and }\end{array}$ & 10 & 8 & 12 & - & - & - & 10 \\
\hline Literature & 12 & 9 & 3 & 0 & 6 & - & 12 \\
\hline Art & 9 & 8 & 21 & 3 & 1 & 11 & 8 \\
\hline Ceramics & 8 & 5 & 5 & 1.5 & 5 & 4 & 8 \\
\hline Arts and humanities & 11 & 8 & 6 & 1 & 5 & 5 & 10 \\
\hline For all theses & 13 & 11 & 6 & 1 & 8 & 27 & 12 \\
\hline
\end{tabular}

In all the disciplines of arts and humanities which fall in the scope of this study, the obsolescence rate for books is higher than the journals. Evaluating the obsolescence rates in terms of disciplines, it has been seen that the youngest citations are in Ceramics and Art, and the oldest ones in English Language and Literature. The half-life of books is 8 years in Ceramics, whereas it is 9 years in Art, 10 years in Philosophy and 12 years in English Language and Literature. Same numbers are also true for journals. The half-life of journals is 5 years in Ceramics, 8 years in Art and Philosophy and 9 years in English Language and Literature.

\section{The Evaluation of the Sources Cited in terms of Lanquages}

This study examines the publication languages of the cited sources in order to find the disciplines that prefer local and foreign literature. Our study illustrates that English sources constitute $56 \%$ of the citations in all the theses. The rate of the citations to Turkish sources is 
41\%. In addition, German, French and Russian sources are also cited to a limited extent. In terms of fields the most frequent use of English sources is in engineering and the most frequent use of Turkish sources is in social sciences (see Figure 2).

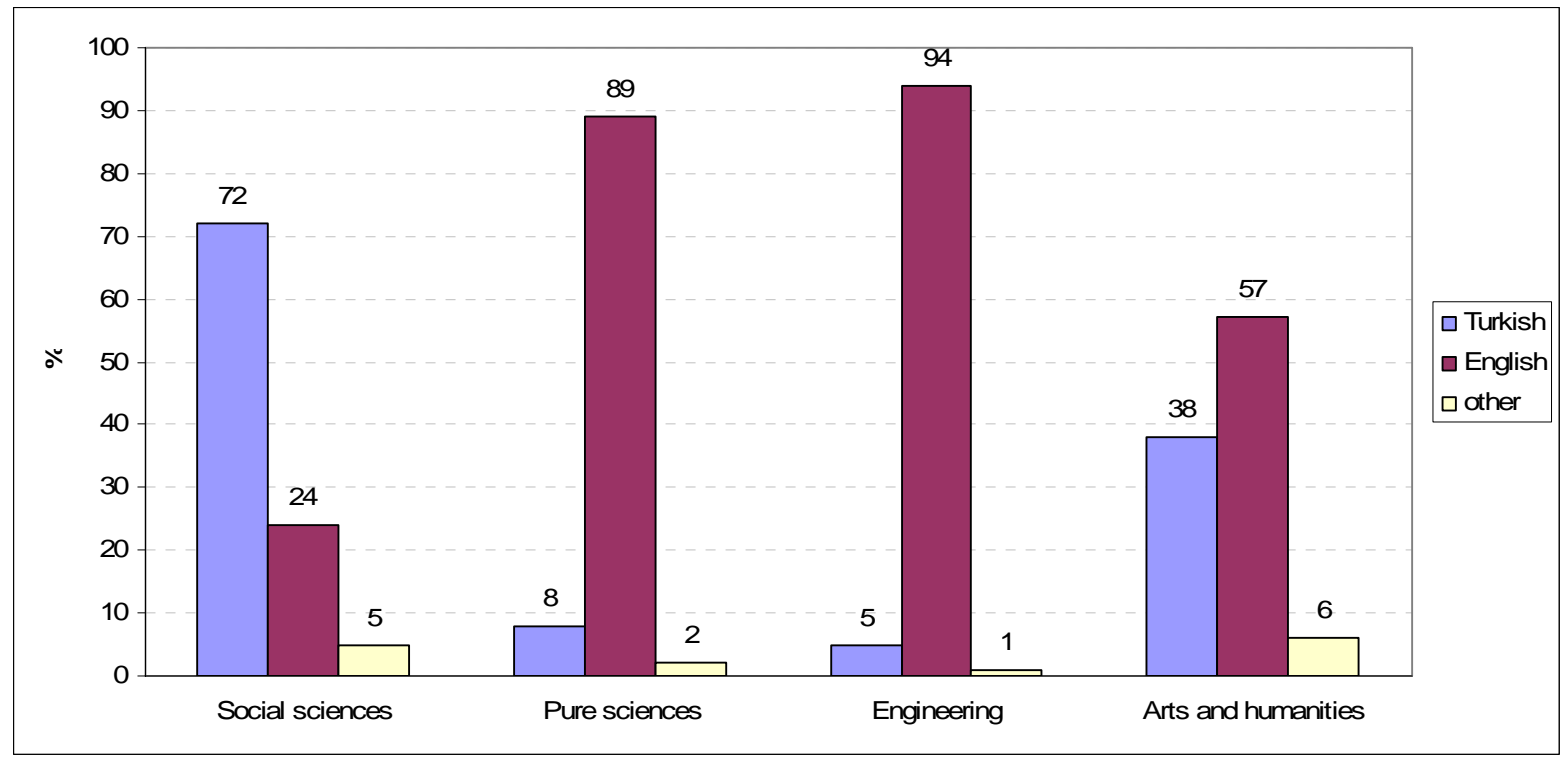

Figure 2. Distribution of citations in terms of languages

In all the disciplines of social sciences, excluding Psychology, Turkish literature is cited more than other literatures. The most frequent use of Turkish literature is seen in History with a rate of $81 \%$. History is followed by Sociology by $79 \%$. In addition to Turkish and English, Russian, German, Arabic and French sources are also cited to a certain extent in History theses.

Contrary to social sciences, in the fields of pure sciences and engineering, in which it is essential to use universal information, the language of citation is predominantly English. Our study illustrates that over $90 \%$ of the sources cited in Mathematics and Chemistry, in which English literature is commonly used, and over $80 \%$ of the sources in Biology and Statistics are in English. It is also worth mentioning that in Chemistry while Turkish sources are barely used, German sources are used more frequently.

In all the disciplines of engineering, the citations to English sources are over 90\% (see Table 7). This rate emphasizes the importance of using universal information and raises questions about whether the Turkish literature has not improved sufficiently at the same time.

In arts and humanities, the use of Turkish sources is common in the disciplines except English Language and Literature. Philosophy, on the other hand, stands out as the discipline in which sources in other languages than Turkish and English are used the most frequently. 
$22 \%$ of the sources cited in Philosophy theses are in another language than English or Turkish. These sources in other languages are usually in French, German and Latin. This condition indicates the need for a wider language range when building philosophy collections.

Table 7. Distribution of citations by languages

\begin{tabular}{|c|c|c|c|c|c|c|c|c|}
\hline \multirow[b]{2}{*}{ Disciplines and fields } & \multicolumn{2}{|c|}{ Turkish } & \multicolumn{2}{|c|}{ English } & \multicolumn{2}{|c|}{ Other } & \multicolumn{2}{|c|}{ Total } \\
\hline & $\mathbf{N}$ & $\%$ & $\mathbf{N}$ & $\%$ & $\mathbf{N}$ & $\%$ & $\mathbf{N}$ & $\%$ \\
\hline Psychology & 233 & 13.3 & 1504 & 86.1 & 9 & 0.5 & 1746 & 99.9 \\
\hline Sociology & 2922 & 78.7 & 776 & 20.9 & 13 & 0.4 & 3711 & 100.0 \\
\hline History & 6571 & 81.2 & 898 & 11.1 & 621 & 7.7 & 8090 & 100.0 \\
\hline Economics & 132 & 67.7 & 63 & 32.3 & - & - & 195 & 100.0 \\
\hline Social sciences & 9858 & 71.7 & 3241 & 23.6 & 643 & 4.7 & 13,742 & 100.0 \\
\hline Statistics & 145 & 17.6 & 678 & 82.3 & 1 & 0.1 & 824 & 100.0 \\
\hline Chemistry & 62 & 2.1 & 2833 & 93.8 & 124 & 4.1 & 3019 & 100.0 \\
\hline Mathematics & 24 & 4.3 & 518 & 93.3 & 13 & 2.3 & 555 & 99.9 \\
\hline Biology & 442 & 11.8 & 3265 & 86.8 & 53 & 1.4 & 3760 & 100.0 \\
\hline Pure sciences & 673 & 8.2 & 7294 & 89.4 & 191 & 2.3 & 8158 & 99.9 \\
\hline Physics Engineering & 49 & 4.1 & 1126 & 94.5 & 17 & 1.4 & 1192 & 100.0 \\
\hline Chemical Engineering & 109 & 6.5 & 1564 & 92.7 & 14 & 0.8 & 1687 & 100.0 \\
\hline Electrical \& Electronic & & & & & & & & \\
\hline Engineering & 49 & 5.8 & 802 & 94.2 & - & - & 851 & 100.0 \\
\hline Computer Engineering & 24 & 3.9 & 597 & 96.1 & - & - & 621 & 100.0 \\
\hline Engineering & 231 & 5.3 & 4089 & 94.0 & 31 & 0.7 & 4351 & 100.0 \\
\hline Philosophy & 422 & 56.0 & 170 & 22.5 & 162 & 21.5 & 754 & 100.0 \\
\hline English Language and & & & & & & & & \\
\hline Literature & 19 & 1.3 & 1455 & 98.7 & - & - & 1474 & 100.0 \\
\hline Art & 364 & 88.3 & 45 & 10.9 & 3 & 0.7 & 412 & 99.9 \\
\hline Ceramics & 347 & 87.2 & 47 & 11.8 & 4 & 1.0 & 398 & 100.0 \\
\hline Arts and humanities & 1152 & 37.9 & 1717 & 56.5 & 169 & 5.6 & 3038 & 100.0 \\
\hline For all theses & 11,914 & 40.7 & 16,341 & 55.8 & 1034 & 3.5 & 29,289 & 100.0 \\
\hline
\end{tabular}

Note: Percentages may not equal $100 \%$ due to rounding.

\section{The Evaluation of the Sources Cited in terms of the Number of Authors}

It is widely known that the rate of single-author and multiple-author works vary according to disciplines. In order to test this case, the citations are analyzed separately in terms of disciplines in this study. In general, $61 \%$ of the sources cited are single-authored and 33\% are multiple-authored. The rate of citations to the publications which do not have author information or corporate authors is $7 \%$.

According to these results, while single-authorship is observed frequently in arts and humanities, multiple-authored sources are cited more commonly in pure sciences and engineering. $64 \%$ of the citations in pure sciences theses are to multiple-authored sources, whereas in engineering this rate is $62 \%$ (see Figure 3 ). 


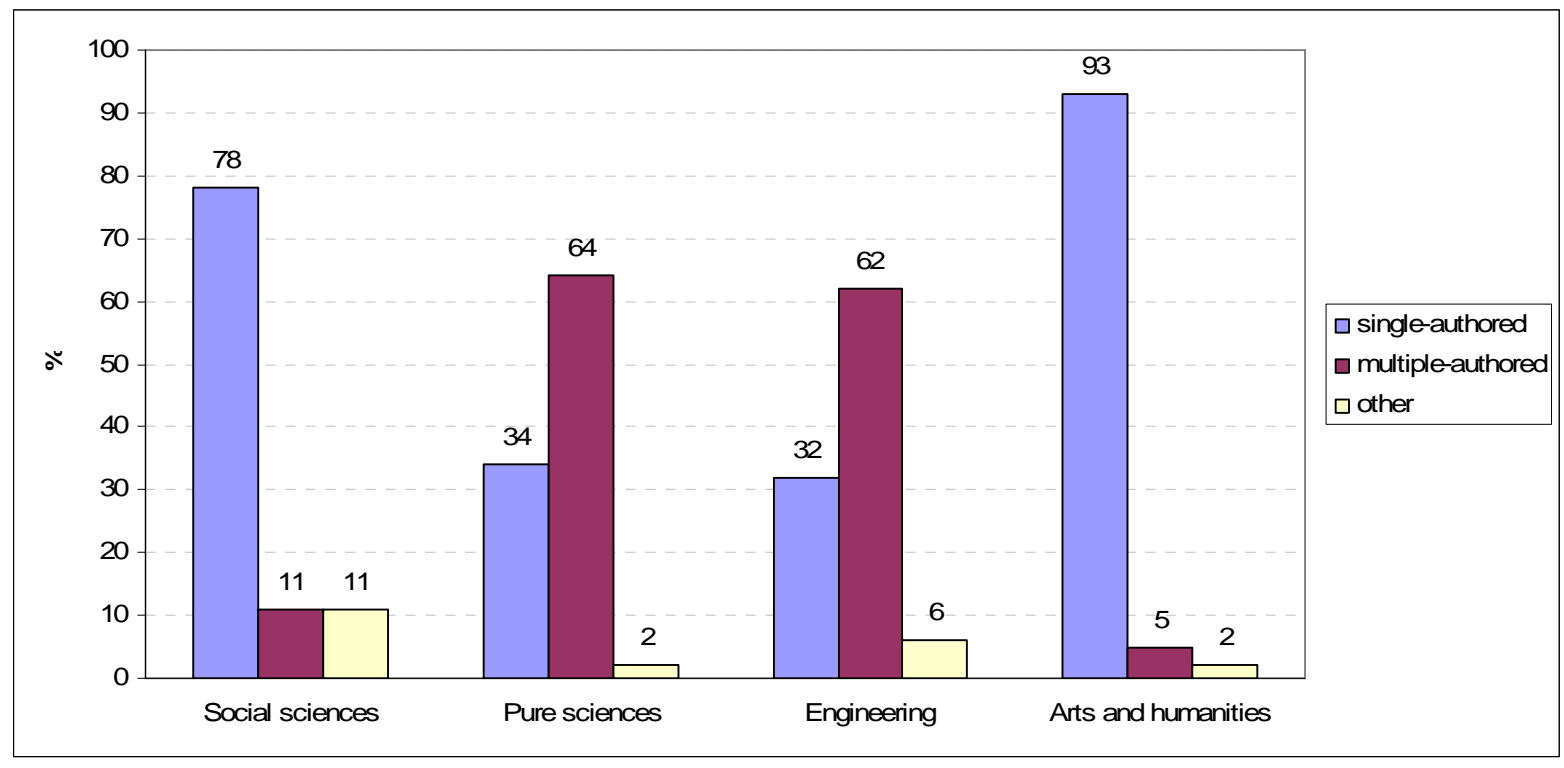

Figure 3. Distribution of authorship patterns by fields

More than half (58.5\%) of the citations in Psychology sources are to multiple-authored sources. In disciplines other than Psychology, single-authored sources are cited more commonly. In History theses, single-authorship is rather dominant and only $3 \%$ of the citations are to multiple-authored sources. This situation shows that individual studies are common in the field of History. On the other hand, in History and Economics, the presence of studies without authors or by corporate authors is noteworthy. This situation is the result of citations to institutional publications in Economics and to archival documents in History.

In pure sciences, in the sources used in Mathematics and Statistics theses, single-authored studies are dominant. In contrast, $73 \%$ of the sources cited in Chemistry theses and $66 \%$ of the sources cited in Biology theses are to multiple-authored publications (see table 8). Compared to Mathematics and Statistics, in Chemistry and Biology, the tendency toward group work and experimental studies leads to the production of more multiple-authored publications, and thus the use of more multiple-authored sources.

In all the disciplines of engineering, citations to multiple-authored sources are more than citations to single-authored sources. In terms of authorship of the sources cited, Chemical Engineering has almost the same features as Chemistry, which is under pure sciences. Also, Chemical Engineering is the discipline with the highest number of citations to multipleauthored publications. In Chemical Engineering theses, almost 3 out of 4 sources cited are multiple-authored. 
Table 8. Distribution of authorship patterns by disciplines and fields

\begin{tabular}{|c|c|c|c|c|c|c|c|c|}
\hline \multirow[b]{2}{*}{ Disciplines and fields } & \multicolumn{2}{|c|}{$\begin{array}{l}\text { Single- } \\
\text { authored }\end{array}$} & \multicolumn{2}{|c|}{$\begin{array}{l}\text { Multiple- } \\
\text { authored }\end{array}$} & \multicolumn{2}{|c|}{ Other } & \multicolumn{2}{|c|}{ Total } \\
\hline & $\mathbf{N}$ & $\%$ & $\mathbf{N}$ & $\%$ & $\mathbf{N}$ & $\%$ & $\mathbf{N}$ & $\%$ \\
\hline Psychology & 713 & 40.8 & 1021 & 58.5 & 12 & 0.7 & 1746 & 100.0 \\
\hline Sociology & 3265 & 88.0 & 258 & 7.0 & 188 & 5.1 & 3711 & 100.1 \\
\hline History & 6675 & 82.5 & 226 & 2.8 & 1189 & 14.7 & 8090 & 100.0 \\
\hline Economics & 122 & 62.6 & 19 & 9.7 & 54 & 27.7 & 195 & 100.0 \\
\hline Social sciences & 10,775 & 78.4 & 1524 & 11.1 & 1443 & 10.5 & 13,742 & 100.0 \\
\hline Statistics & 438 & 53.2 & 349 & 42.4 & 37 & 4.5 & 824 & 100.1 \\
\hline Chemistry & 776 & 25.7 & 2214 & 73.3 & 29 & 1.0 & 3019 & 100.0 \\
\hline Mathematics & 380 & 68.5 & 173 & 31.2 & 2 & 0.4 & 555 & 100.1 \\
\hline Biology & 1187 & 31.6 & 2495 & 66.4 & 78 & 2.1 & 3760 & 100.1 \\
\hline Pure sciences & 2781 & 34.1 & 5231 & 64.1 & 146 & 1.8 & 8158 & 100.0 \\
\hline Physics Engineering & 380 & 31.9 & 789 & 66.2 & 23 & 1.9 & 1192 & 100.0 \\
\hline Chemical Engineering & 415 & 24.6 & 1238 & 73.4 & 34 & 2.0 & 1687 & 100.0 \\
\hline Electrical \& Electronic & & & & & & & & \\
\hline Engineering & 347 & 40.8 & 372 & 43.7 & 132 & 15.5 & 851 & 100.0 \\
\hline Computer Engineering & 241 & 38.8 & 309 & 49.8 & 71 & 11.4 & 621 & 100.0 \\
\hline Engineering & 1383 & 31.8 & 2708 & 62.2 & 260 & 6.0 & 4351 & 100.0 \\
\hline Philosophy & 730 & 96.8 & 18 & 2.4 & 6 & 0.8 & 754 & 100.0 \\
\hline English Language and & & & & & & & & \\
\hline Literature & 1356 & 92.0 & 97 & 6.6 & 21 & 1.4 & 1474 & 100.0 \\
\hline Art & 385 & 93.4 & 14 & 3.4 & 13 & 3.2 & 412 & 100.0 \\
\hline Ceramics & 341 & 85.7 & 30 & 7.5 & 27 & 6.8 & 398 & 100.0 \\
\hline Arts and humanities & 2812 & 92.6 & 159 & 5.2 & 67 & 2.2 & 3038 & 100.0 \\
\hline For all theses & 17,751 & 60.6 & 9622 & 32.9 & 1916 & 6.5 & 29,289 & 100.0 \\
\hline
\end{tabular}

Note: Percentages may not equal $100 \%$ due to rounding.

In the arts and humanities disciplines except Ceramics, over $90 \%$ of the citations are singleauthored. The rate of single authorship in the sources cited in the Ceramics theses is $86 \%$ (see table 8). General characteristics of the fields of arts and humanities and the individual study habits of researchers in these fields lead the literature in this field to consist of mostly singleauthored sources.

\section{Conclusion}

This study shows that there is a relationship among the source type used, obsolescence rates of the sources, publication language, and number of authors in the citations of theses. Use of books, slow obsolescence rate, and citations to Turkish and single-authored sources are common in arts and humanities use of journals; fast obsolescence rate, citations to English and multiple-authored sources are common in pure sciences and engineering.

The results show differences among fields and disciplines in terms of use of sources and literature obsolescence. The results obtained here are generally parallel to the findings reported elsewhere in the literature. This shows the determinant effect of academic discipline 
in using information. The results of this study overlap the findings in the literature to a great extent. All in all, we must conclude that while preparing collection policies, it is necessary to pay attention to interdisciplinary differences and to reflect users' typical choices of sources for each discipline.

\section{Acknowledgement}

This study was supported in part by a research grant of the Turkish Scientific and Technological Research Centre (SOBAG-107K505). We thank the members of the project team (Pınar Al, Sezin Tiryaki Ersen, Çağdaş Çapkın and Sibel Al) for providing data used in this study.

\section{References}

Al, U., \& Y. Tonta. 2004. Atıf analizi: Hacettepe Üniversitesi Kütüphanecilik Bölümü tezlerinde atıf yapılan kaynaklar (Citation analysis: Sources cited in dissertations completed at Hacettepe University Department of Librarianship). Bilgi Dünyası 5(1): 19-47.

Beile, PM., DN. Boote, \& EK. Killingsworth. 2004. A microscope or a mirror?: A question of study validity regarding the use of dissertation citation analysis for evaluating research collections. Journal of Academic Librarianship 30(5): 347-353.

Brazzeal, B., \& R. Fowler. 2005. Patterns of information use in graduate research in forestry: A citation analysis of Masters theses at Mississippi State University. Science \& Technology Libraries 26(2): 91-106.

Broadus, RN. 1971. The literature of the social sciences: A survey of citation studies. International Social Sciences Journal 23: 236-243.

Buttlar, L. 1999. Information sources in library and information science doctoral research. Library and Information Science Research 21: 227-245.

Clarke, ME., \& C. Oppenheim. 2006. Citation behaviour of information science students II: Postgraduate students. Education for Information 24(1): 1-30.

Clemens, ES., WW. Powell, K. McIlwaine, \& D. Okamoto. 1995. Careers in print: Books, journals, and scholarly reputations. The American Journal of Sociology 101(2): 433-494.

Cullars, J. 1992. Citation characteristics of monographs in the fine arts. Library Quarterly 62(3): 325-342.

Cunningham, SJ., \& D. Bocock. 1995. Obsolescence of computing literature. Scientometrics 34(2): 255-262. 
Edwards, S. 1999. Citation analysis as a collection development tool: A bibliometric study of polymer science theses and dissertations. Serials Review 25: 11-20.

Gooden, AM. 2001. Citation analysis of chemistry doctoral dissertations: An Ohio State University case study. Issues in Science \& Technology Librarianship 32. URL: http://www.istl.org/01-fall/refereed.html [viewed October 29, 2008].

Gökkurt, Ö. 1997a. Citation indeks ve ‘citation’ analizi: Enformetrik bir model çalışması, (Citation index and citation analysis: The study of an informetric model). Unpublished dissertation, Ankara University, Ankara, Turkey.

Gökkurt, Ö. 1997b. Yoğunlaşma teorisi ve atıf analizinde kullanımı (Concentration theory and it’s use in citation analysis). In Kütüphanecilik Bölümü 25. Yıla Armağan, ed. B. Yılmaz, 153-161. Ankara: Hacettepe University.

Haycock, LA. 2004. Citation analysis of education dissertations for collection development. Library Resources \& Technical Services 48(2): 102-106.

Heinzkill, R. 1980. Characteristics of references in selected scholarly English literary journals. Library Quarterly 50: 352-365.

Herubel, J-PVM. 1991. Philosophy dissertation bibliographies and citations in serials evaluation. Serials Librarian 20: 65-73.

Kushkowski, JD., KA. Parsons, \& WH. Wiese. 2003. Masters and doctoral thesis citations:

Analysis and trends of a longitudinal study. portal: Libraries and the Academy 3: 459479.

Kuyper-Rushing, L. 1999. Identifying uniform core journal titles for music libraries: A dissertation citation study. College \& Research Libraries 60: 153-163.

Lindholm-Romantschuk, Y., \& J. Warner. 1996. The role of monographs in scholarly communication: An empirical study of philosophy, sociology and economics. Journal of Documentation 52(4): 389-404.

Okiy, RB. 2003. A citation analysis of education dissertations at the Delta State University. Abraka, Nigeria. Collection Building 22(4): 158-161.

Pinelli, T. 1991. The information-seeking habits and practices of engineers. Science and Technology Libraries 11(3): 5-25.

Pinelli, T., AP. Bishop, RO. Barclay, \& JM. Kennedy. 1993. The information-seeking behavior of engineers. In Encyclopedia of Library and Information Science, ed. A. Kent \& CM. Hall, 52(Supp. 15): 167-201. New York: CRC Press.

Schaffer, T. 2004. Psychology citations revisited: Behavioral research in the age of electronic resources. Journal of Academic Librarianship 30(5): 354-360. 
Sexton, E. 2006. Journal use by graduate students as indicated by Masters theses bibliographies at an Urban Commuter College, 1991-2004. Behavioral \& Social Sciences Librarian 24(2): 93-111.

Shontz, D. 1992. The serial/monograph ratio in psychology: Application at the local level. Behavioral \& Social Sciences Librarian 11(2): 91-105.

Sinn, RN. 2005. A local citation analysis of mathematical and statistical dissertations. Science \& Technology Libraries 25(4): 25-37.

Slutz, MJ. 1997. A citation analysis of Master level English theses submitted to the Department of English-Kent State University, 1985-1995. URL: http://eric.ed.gov/ERICDocs/data/ericdocs2sql/content_storage_01/0000019b/80/15/10/ 7b.pdf [viewed October 29, 2008].

Stern, M. 1983. Characteristics of the literature of literary scholarship. College \& Research Libraries 44(4): 199-209.

Sylvia, M., \& M. Lesher. 1995. What journals do psychology graduate students need? A citation analysis of thesis references. College \& Research Libraries 56: 313-318.

Tenopir, C., \& D. King. 2004. Communication patterns of engineers. New York: John Wiley \& Sons, Inc.

Tonta, Y., \& U. Al. 2006. Scatter and obsolescence of journals cited in theses and dissertations of librarianship. Library \& Information Science Research 28(2): 281-296.

Uçak, NÖ. 2004. User studies in Turkey: An evaluation of dissertations. Information Development 20: 122-129.

Uçak, NÖ. 2007. Kütüphanecilik ve bilgi yönetimi literatüründe kullanıcı (Users in literature of librarianship and information management). In Değişen Dünyada Bilgi Yönetimi Sempozyumu, 24-26 Ekim 2007, Hacettepe Üniversitesi, Ankara, ed. Kurbanoğlu, S., Y. Tonta, \& U. Al, 113-120. Ankara: Hacettepe University.

Walcott, R. 1991. Characteristics of citations in geoscience doctoral dissertations accepted at United States academic institutions 1981-1985. Science \& Technology Libraries 12(2): 5-16.

Walcott, R. 1994. Local citation studies: A shortcut to local knowledge. Science \& Technology Libraries 14(3): 1-14.

Waugh, CK., \& M. Ruppel. 2004. Citation analysis of dissertation, thesis, and research paper references in workforce education and development. Journal of Academic Librarianship 30(4): 276-284. 
Wehmeyer, JM., \& S. Wehmeyer. 1999. The comparative importance of books: clinical psychology in the health sciences library. Bulletin of the Medical Library Association 87(2): 187-191.

Xhignesse, LV., \& CE. Osgood. 1967. Bibliographical citation characteristics of the psychological journal network in 1950 and 1960. American Psychologist 22: 778-791.

Yılmaz, B. 1997. Hacettepe Üniversitesi Edebiyat Fakültesi Kütüphanecilik Bölümü lisansüstü tezlerinin niceliksel ve konusal analizi: 1974-1997 (The qualitative analysis of postgraduate theses at Hacettepe University, Faculty of Letters, Department of Librarianship: 1974-1997). In Kütüphanecilik Bölümü 25. Yıla Armağan, ed. B. Yılmaz, 191-198. Ankara: Hacettepe University.

Yılmaz, M. 1999. Kütüphane ve bilgibilimi açısından bibliyometrinin önemi (The importance of bibliometrics regarding to library and information science). Unpublished Master Degree thesis. İstanbul University, İstanbul.

Yontar, A. 1998. Türkiye'de kütüphane ve bilgi bilimi konusundaki başlıca araştırma sorunlarının lisansüstü tezlerinde yansıması (The reflections of the fundamental research problems related to library and information science studies in Turkey on the postgraduate theses). Kütüphanecilik Dergisi: Belge Bilgi Kütüphane Araştırmaları 4:117.

Zipp, LS. 1996. Thesis and dissertation citations as indicators of faculty research use of university library journal collections. Library Resources \& Technical Services 40: 335342.

Editorial history:

Paper received 7 November 2008

Revised version received 14 April 2009

Accepted 1 May 2009. 